\title{
Conflicts of Law and Constitutional Law
}

\author{
W. Müller-Freienfels $\dagger$
}

As Max Rheinstein pointed out, "The states' freedom to fashion their own laws of conflict of laws is limited by the Constitution of the United States as interpreted by the Supreme Court of the United States." In particular, the due process clause of the fourteenth amendment, ${ }^{2}$ the privileges and immunities clause ${ }^{3}$ and the full faith and credit clause ${ }^{4}$ have been interpreted ${ }^{5}$ to prevent a state from applying its own law to controversies having no significant connection with the forum state ${ }^{6}$ and to guarantee citizens of one state equal and fair treatment in the courts of another state. ${ }^{7} \mathrm{In}$ deed, it once seemed that the Supreme Court was slowly shaping a system of federal conflicts rules. ${ }^{8}$ Although this trend toward using

$\dagger$ Director of the Institute for Private International Law, University of Freiburg.

' Rheinstein, United States of America, in 1 INTERNational. ENCYCLOPEdia of ComparaTive Law U-159 (1976). See also Bernstein, Ein Kollisionsrecht für die Verfassung, 18 NeUE JURISTISCHE WOCHENSCHRIFT [NJW] 2273 (1965); Leflar, Constitutional Limits on Free Choice of Law, 28 J. L. \& Contemp. ProB. 706 (1963); Rheinstein, The Constitutional Bases of Jurisdiction, 22 U. Car. L. REv. 775 (1955); Ross, Has the Conflict of Laws Become a Branch of Constitutional Law? 15 MiNN. L. Rev. 161 (1931). On a broader level Max Rheinstein contributed the following essay in honor of his teacher, Emst Rabel: Rheinstein, Das Kollisionsrecht im System des Verfassungsrechts der Vereinigten Staaten von Amerika, in 1 FESTSCHRIFT FOR ERNST RABEL 539 (1954).

2 U.S. ConsT. amend. XIV, $\S 1$.

${ }^{3}$ U.S. Const. art. IV, $\S 2$, cl. 1.

+ U.S. Const. art. IV, $\S 1$.

S See Martin, Constitutional Limitations on Choice of Law, 61 CoRnenL L. Rev. 185 (1976); Kirgis, The Role of Due Process and Full Faith and Credit in Choice of Law, 62 Cornell L. Rev. 94 (1976); Martin, A Reply to Professor Kirgis, 62 Cornell. L. Rev. 151 (1976).

- See Hartford Accident \& Indem. Co. v. Delta \& Pine Land Co., 292 U.S. 143, 149-50 (1934) (decided on equal protection grounds; full faith and credit claims noted but not considered).

' Hughes v. Fetter, 341 U.S. 609, 611-13 (1951) (full faith and credit); Blake v. McClung, 172 U.S. 239, 254 (1898) (privileges and immunities). See also cases in note 8 infra.

${ }^{*}$ See Order of United Commercial Travelers v. Wolfe, 331 U.S. 586, 589, 606-07 (1947) (full faith and credit); Bradford Elec. Light Co. v. Clapper, 286 U.S. 145, 154, 159-60 (1932)(same); Home Ins. Co. v. Dick, 281 U.S. 397, 411 (1930)(due process); Horowitz, Toward a Federal Common Law of Choice of Law, 14 U.C.L.A. L. REv. 1191 (1967).

For a full discussion of the question to what extent federal courts may develop federal common law including conflicts law in the light of Erie R.R. v. Tompkins, 304 U.S. 64 (1938), and Klaxon Co. v. Stentor Elec. Mfg. Co., 313 U.S. 487 (1941), see Hay, Unification of Law in the United States: Uniform State Laws, Treaties and Judicially Declared Federal Common Law, in Legal Thought in the United States Under Contemporary Pressures 261, 273-93 (J. Hazard \& W. Wagner eds. 1970). Cf. Miree v. DeKalb County, 433 U.S. 25, 28-33 (1977) (state, not federal, law governs litigation by the third-party beneficiary of a federal contract); Wallis v. Pan Am. Petroleum Corp., 384 U.S. 63, 67-72 (1966)(state and not federal law 
the national constitution as the source of a federal common law of conflicts has subsided, ${ }^{9}$ constitutional scrutiny of state conflict of laws decisions has not. Specifically, American courts now employ a governmental interest analysis to determine whether a state may constitutionally apply its own law to particular disputes. ${ }^{10}$

In contrast, European lawyers and courts have only recently recognized that constitutional law affects choice of law decisions. ${ }^{11}$ The American emphasis on the importance of constitutional law in the conflicts area has undoubtedly influenced this European development. But it should be underscored that the interface between conflicts and constitutional law in many European countries does not parallel the American experience. For one thing, choice of law questions in the United States generally concern relationships within the legal system, while in Europe questions of private international law mainly concern the relationship between the domestic legal system as a whole and foreign legal systems. The problems are more truly international. This difference has perhaps been underemphasized in the United States where "little distinction is made between cases involving sister states of the United States and cases involving foreign nations." 12 A judge in deciding interstate or inter-

governs dispute between private parties concerning an oil lease for federal land); Bank of Am. Nat'l Trust \& Sav. Ass'n v. Parnell, 352 U.S. 29, 33, 34 (1956)(state and not federal law governs dispute between private parties concerning federally guaranteed bonds); Clearfield Trust Co. v. United States, 318 U.S. 363, 367 (1943) (federal and not state law governs obligations arising from commercial paper issued by the United States).

- See B. Curre, Selected Essays on the Conrlict of Laws 238-41 (1963).

1" E.g., Pearson v. Northeast Airlines, Inc., 309 F.2d 553, 559 (2d Cir. 1962), cert. denied, 372 U.S. 912 (1963). See generally Currie, The Constitution and the Choice of Law: Governmental Interests and the Judicial Function, 26 U. CHI. L. REv. 9 (1958), reprinted in B. Currie, Selected Essays on the Conflict of Laws 188 (1963).

"See T. Ballarino, Costituzione e Diritto Internazionale Privato 123 (1974); Bernstein, Ein Kollisionsrecht für die Verfassung, 18 NJW 2273 (1965); Egido, Influencia del Derecho constitucional en la configuracion de nuevas reglas de conflicto: examen de la jurisprudencia civil de nuestro Tribunal Supremo de 1933 a 1937 en la determinacion de la ley aplicable a las relaciones personales entre conyuges, 25 REvista ESPAÑoLA DE DERECHO INTERNACIONal 327 (1972); Framont, République Fédérale d'Allemagne: les principaux́ evénements législatifs et jurisprudentiels survenus en 1971, 88 REvUE DU DroIT PUBLIC ET DE LA Science Pouttque en France et $\lambda$ L'Etranger 1443, 1456-57 (1972); Kegel, Embarras de richesse, 36 Rabels Zeitschrift für Ausländisches und Internationales Privatrecht [RABELSZ] 27 (1972); Labrusse, Droit constitutionnel et droit international privé en Allemagne fédérale (à propos de la décision du Tribunal Constitutionnel fédéral du 4 mai 1971), 63 Revue Critique de Drott International Privé [Rev. Crit. D. Droit Int. P.] 1 (1974); Schwind, Verfassung und internationales Privatrecht-Unzeitgemässe Betrachtungen zu

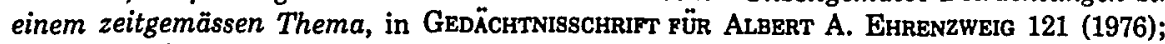
Wengler, Die Bedeutung der verfassungsrechtlichen Bestimmungen über die Eheschliebungsfreiheit und den Schutz der Familie für das internationale Privatrecht, 36 RABELSZ 116 (1972).

12 Rheinstein, supra note 1, at U-159. 
provincial conflicts questions remains within his own legal system, while a judge in truly international situations applies genuinely foreign law. For this reason, it is not unreasonable to ask the judge in a federal system deciding interstate cases to help to develop the "foreign" law, but it is asking too much to expect a judge of one country to speculate on the policies underlying the laws of another country. The problem a judge faces in attempting to determine the "constitutionality" of foreign statutes is a striking example of this. ${ }^{13}$

Second, constitutional law serves a variety of disparate functions in different countries. In the United States, Canada, Australia, Italy, Austria, Norway, Japan, and the Federal Republic of Germany, for instance, the primacy of constitutional law is established. ${ }^{14}$ This theoretical primacy has a direct impact on individual cases. Indeed, some commentators in countries such as Italy and the Federal Republic of Germany argue that no private international law decision should be rendered without considering constitutional law principles and scrutinizing applicable domestic and foreign principles for their compatibility with domestic constitutional rights. ${ }^{15}$ In contrast, England's system of parliamentary sovereignty

${ }^{13}$ Kahn-Freund, International Law and Economic Order, in EsSAys IN HoNOR OF F.A. MANN 207, 224-25 (1977).

i See, for the United States, J. Roche, Courts and Rights: The American Judiciary in Action 58-92 (1961); P. Kauper, Constitutional Law: Cases and Materials 599-831 (4th ed. 1972); for Canada, J. Brossard, La Cour Suprême ET la Constitution 149-50, 224-25 (1968) (there is "no doubt that the text and customs which take the place of a Constitution [for Canada] form its 'fundamental law' "); for Australia, Commonwealth of Australia Constitution Act, 1900, 63 \& 64 Vict., c.12, § 5; D. Derham, F. Maher \& P. Waller, AN INTroduction To LAw 68, 69 (2d ed. 1971); for Italy, Costituzione [Cost.] art. CXXXIV (Italy); G. Balladote-Pallieri, Diritto costituzionale 329 (9th ed. 1970); Ballarino, Costituzione e diritto internazionale privato, 24 Diritto InTERnazionale 18, 36 (1970); for Austria, Bundesverfassung arts. CXL, CXLa (Aus.); L. AdaMovich, HaNDBuCH DES Österreichischen Verfassungsrechts 100 (6th ed. 1971); F. Ermacora, Osterreichische VerfassungsLehre 229 (1970); for Norway, J. Andenaes, The United States of America 1776, Norway 1814 at 7 (1976); F. Castberg, Die Zuständigkeit der Gerichte in USA und Norwegen zur Prüfung DER VERfassungsmass IGKeIT von GESETZEN 10-11 (1960); Eckhoff, Impartiality, Separation of Powers, and Judicial Independence, 9 Scandinavian Studies in Law [Scan. Stud. Law] 9, 23-29 (1965); as to the interrelation between the Norwegian Constitution and international treaties and organizations, see Opsahl, Limitation of Sovereignty Under the Norwegian Constitution, 13 Scan. Stud. Law 151, 154-77 (1969); for Japan, Kenpo (Constitution) arts. LXXXI, XCVIII (Japan); E. Hillach, Die VerfassungsgerichtsbarkeIt Japans 59 (1974); W. Rohl, Die japanische Verfassung, in IV Die StaAtsverfassungen DER WeLt 136-37, 14243 (1963); RöHL, DIE JAPANISCHE VERFASSUNG 136-37, 142-43, in IV Die Staatsverfassungen der Welt, (1963); for the Federal Republic of Germany, GRUNDGeseTz [GG] arts. LXXIX \& XX, para. 3 (W.Ger.); K. Hesse, Grundzüge des Verfassungsrechts der Bundesrepublik Deutschland 79 (9th ed. 1976); Deutsch, The German Federal Republic, in Modern Political Systens: Europe 393 (R. Macridis \& R. Ward eds. 3d ed. 1972).

is See J. Kropholler, Gleichberechtigung durch Richterrecht 89 (1975); L. RaApe \& F. Sturm, Internationales Privatrecht 206, 221 (6th ed. 1977); Juenger, Möglichkeiten einer Neuorientierung des internationalen Privatrechts, 26 NJW 1521, 1524 (1973). But see Beitzke, 
has rejected the view that the "constitution"-whatever this word may mean in the British context-is higher in the hierarchy of norms than an ordinary statute or a decision of the House of Lords. ${ }^{16}$ The provisions of Switzerland's written constitution do not.empower courts to invalidate contrary federal statutes. ${ }^{17}$ In Norway the case law since the end of the Second World War has made the idea that a court of law should invoke the constitution to invalidate an act of Parliament seem like a thing of the past, although the Norwegian Supreme Court has overruled an act of Parliament on three occasions. ${ }^{18}$

It is not my task here to suggest that either of these approaches is wrong or inappropriate. It is one thing if a constitution is created in a democratic country which has experienced the terror of a totalitarian government and is therefore especially concerned with averting a repetition of this experience through, inter alia, constitutional guarantees. It is another if a constitution has evolved in a country with a heritage of democracy, individual liberty, and an unimpeded, sovereign Parliament. ${ }^{19}$

With these qualifications in mind, I will discuss two problems of the relationship between conflicts and constitutional law in a

Nationales Recht für internationale Sachverhalte?, 111 ANZEIGER DER OSTERREICHISCHEN AKAdemie der Wissenschaften, Philosophisch-Historishe Klasse 295-96 (1974); Henrich, Verfassungswidrige Kollisionsnormen-ein Rechtschaos? 38 RABELsZ 490 (1974).

i See A. Dicey, Introduction to the Study of the Law of the Constitution 203 (10th ed. 1959); W. Jennings, The Law and the Constitution 313-14 (5th ed. 1959); O. Phillips, Constitutional and Administrative Law 36 (5th ed. 1973); Lloyd of Hampstead, Do We Need a Bill of Rights? 39 MoD. L. REv. 121, 125-29 (1976).

${ }^{17}$ A. Favre, Droit constitutionnel suisse 252 (2d ed. 1970). The Swiss do not share the German position that recognizes a sphere of individual rights superior even to the constitution, but they may be moving closer to it. H. OberhäNSLI, Die GewährLeistuNG DER FreiheitsRECHTE UNTER BESONDERER BERÜCKSICHTIGUNG DER VERFASSUNGSMÄSSIGEN GARANTIE DER PERsönlichen Freihert 70-75 (1971); P. Saladin, Grundrechte im Wanded 382-85 (1970). The preliminary draft of the new Swiss federal constitution (published February 23, 1978, by Bundesrat Kur Furgler) supports this thesis.

See, for France, J. CADART, 1 Instrtutions POLITIQUES ET DRolt CONSTITUTIONNEL 148 (1975); Roche, LIBERTÉs polITIQues 38, 39 (4th ed. 1976). But see Constitution arts. LVI-LXIII (Fr. 1958, amended 1974) and Ordonnance no. 58-1067 du 7 novembre 1958 sur le Conseil constitutionnel, arts. 17-26, [1958] Bulletin Législatif Dalloz [B.L.D.] 383, [1958] JurisClasseur Périodique, la Semaine Juridique [J.C.P.] III no. 23636, as amended by Loi constitutionnelle no. 74-904 du 29 octobre 1974 portant révision de l'article 61 de la Constitution, [1974] B.L.D. 344, [1974] J.C.P. III no. 42167. See, for Belgium, P. WIGNY, Cours DE DRoIT consttTutionnel 137 (1973); for The Netherlands, P. Oud, II Het Constitutioneel Recht van HET KoninkruJK DER NEDERLANDEN 627, 668 (2d ed. 1970); Koopmans, The Netherlands, in 1 International Encyclopedia of Comparative LaW N-13 (1971) (see Statut voOR HET KoninKRIJK DER NEDERLANDEN art. CXXXI (Neth.)).

18. J. ANDENaEs, supra note 14, at n.7.

" But see Kahn-Freund, The Impact of Constitutions on Labour Law, 35 CAMBridge L. J. 240, 250 (1976). 
general way. First, I will analyze the problem arising when a country's conflicts principles violate its constitution. Then I will treat questions that arise when a country's conflicts rules mandate application of a foreign law that is unconstitutional as measured against the constitution of the forum state. ${ }^{20}$

\section{Unconstitutional Conflicts Rules}

\section{A. Theoretical Considerations}

Contemporary American lawyers may find it surprising that unconstitutional conflicts rules warrant special discussion; it may seem axiomatic that a rule of law which contravenes a constitutional provision may not be enforced. This view assumes the supremacy of constitutional law and the existence of judicial jurisdiction to review the constitutionality of statutes. As noted earlier, ${ }^{21}$ however, some nations do not accord constitutional law primacy, and although the power of judicial review is guaranteed, for example, in Italy and the Federal Republic of Germany, it is not universally recognized. ${ }^{22}$ But for the important problems concerning the relation between conflicts and constitutional law to arise, constitutional law must be accorded primacy and judicial review must exist to implement that primacy. The remaining discussion will therefore assume these conditions.

Even in nations that grant primacy to constitutional law, it is not indisputable that courts with constitutional review jurisdiction should invalidate "unconstitutional" conflicts rules. Some scholars have argued that the rules of private international law should not

${ }^{20}$ The third problem in this context may be only mentioned here: what should a court do when the applicable foreign law may be unconstitutional when measured against the foreign state's paramount constitution? It is not enough to say a foreign statute that is unconstitutional when tested against the foreign constitution should not be applied because it is not the law of the foreign state. The foreign country may have special constitutional courts to which the power of constitutional review is restricted and it may be impossible to get the constitutional question before one of these courts. See Judgment of September 13, 1954, Trib., Rome, 47 Rev. Crit. D. Droit INT. P. 534, 535 (1958) note R. DeNova; KahnFreund, supra note 13, at 224; Neumayer, Fremdes Recht und Normenkontrolle, 23 RABELSZ 573,586 (1958). Moreover, in many situations it is difficult to determine the desirability and feasibility of putting "a judge who has to apply foreign law in the position of his opposite number and therefore to allow him to inquire into the validity of foreign legislation within the limits set by foreign law." F. MANN, Studies in INTERnattonal Law 445 (1973).

21 See text and notes at notes 14-18 supra.

22 In Italy, the constitutionality of a statute may be reviewed in a special non-adversary procedure. CosT. art. CXXXIV. In West Germany, constitutional review of a statute may take place in a suit instituted by a private individual or in a special non-adversary proceeding at the instance of the federal or state government or of one-third of the members of the Federal Diet (Bundestag). GG art. XCIII, para. 1, nos. 2 \& 4a. 
be viewed as positive, national law but rather as transnational prescriptions that are not subject to any national constitution. ${ }^{23}$ The conflicts rules are simply neutral, formal provisions-rules of expediency, devoid of substantive justice. ${ }^{24}$ Furthermore, it might be argued, the participants in the establishment of the constitution probably never intended that constitutional provisions such as those providing equal rights to spouses or between legitimate and illegitimate children should be applied to conflicts rules..$^{25}$ Rather, the existence of these rules was presupposed in drafting the individual country's constitution. Since the constitutional provisions were adopted within the framework of existing conflicts law, the argument runs, constitutional law should be considered subject to private international law in the hierarchy of norms.

The progressive reformulation of domestic conflicts rules during the last century has clearly demonstrated, however, that the rules of private international law have their origin in national law. ${ }^{26}$ Conflicts principles are based on the authority of a single country to create its own law and apply it to individuals subject to that authority. Moreover, the view that conflicts rules are merely formal, neutral principles ignores the necessity of an international justice. ${ }^{27}$ Every state has an interest in applying its own law-the law that

2 E. Frankenstein, 1 Internationales Privatrecht 19-27 (1926)(the force of laws emanating from countries in international groups derives from the group, and not from the individual countries). See also W. NIEDERER, EINFÜHRUNG IN DIE ALLGEMEINEN LEHREN DES internationalen Privatrechts 139 (3d ed. 1961)(international private law as applied by judges has the force of law, beyond unsecured right). But see E. Zitelmann, 1 InTERnationales Privatrecht 74-76 (1897).

${ }^{24}$ Esser, Interpretation und Rechtsneubildung im Familienrecht, [1953] JURISTENZEITUNG [JZ] 521, 524; Ferid, Wechselbeziehungen zwischen Verfassungsrecht und

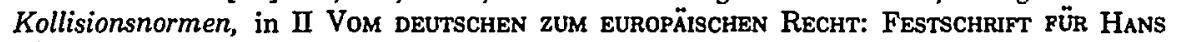
DöLLE 119, 135-36 (1963); Finke, Erläuterungen zum Gleichberechtigungsgesetz, 11 Monatsschrift FÜR Deutsches REcht [MDR] 449, 455 (1957); Jayme, Kindesherausgabeansprüche italienischer Eltern in Verfahren vor deutschen Gerichten, 11 Zeitschript pür das Gesamte FamilenRecht [FamRZ] 352, 355 (1964); Kahn-Freund, General Problems of Private International Law, [143] III RECuEIL DEs Cours DE L'ACAdÉmie DE Droit International de La Haye [REc. D. C.] 139, 234 (1974); Sonnenberger, Sind die familienrechtlichen Artikel des EGBGB mit dem Grundgesetz vereinbar? (Erwiderung), 18 MDR 283, 285 (1964).

${ }^{25}$ G. Kegel, Internationales Privatrecht 339 (4th ed. 1977). See also Braga, Die Gleichberechtigung von Mann und Frau und das deutsche internationale Privatrecht, 6 MDR 266, 268 (1952); Neumayer, Ist das deutsche internationale Kindschaftsrecht revisionsbedürftig? 152 ARchiv für die Civisistische Praxis 335, 335-36 (1952/53).

26 But see 0. Kahn-Freund, The Growth of Internattonalism in English Private InterNational LaW (1960); G. KEGEL, supra note 25, at 54; Kötz, Allgemeine Rechtsgrundsätze als Ersatzrecht, 34 RABELsZ 663, 669-78 (1970); Kegel, The Crisis of Conflict of Laws, [112] II REC. D. C. 91, 95-263 (1964).

${ }^{27}$ See, e.g., Kegel, Begriffs-und Interessenjurisprudenz im internationalen Privatrecht, in Festschrift Hans Lewald 259, 259-88 (1953). 
its citizens and judges know. But conflicts principles are needed to guide the discovery and application of the most appropriate law in particular controversies.

Furthermore, it is an unfounded petitio principii that constitutional orders do not apply to conflicts principles. No constitution expressly excepts conflicts rules from its reach. Conflicts rules do reflect special value judgments and should therefore be valid only if in accord with the applicable principles of substantive justice embodied in the constitution. ${ }^{28}$ There are, for example, numerous practical disadvantages for wives resulting from the rule that in domestic disputes the law of the husband's nationality or residence is to be applied..$^{29}$ This rule cannot be defended as neutral or valuefree. It ignores the fact that the law of the wife's nationality or residence is generally most appropriate for application to her yet it gives controlling weight to the same consideration in the husband's case. Moreover, the wife, unlike the husband, is not afforded the opportunity to influence the choice of law determination by acquiring a new nationality. Thus the arguments for excepting conflicts principles from constitutional restrictions are unpersuasive.

Determining whether a constitutional provision applies to conflicts rules may at times be difficult, but there will be clear cases. The drafters of the German constitution, for example, declared that all regulations contrary to particular provisions of the constitution would automatically become ineffective on a date certain. ${ }^{30}$ German choice of law statutes contravening those provisions must be disregarded, and the courts must decide conflicts questions that would otherwise be governed by such provisions on a case-by-case basis. However, courts faced with this situation ${ }^{31}$ should, out of due regard for the primacy of the legislature in a republic, hew as closely as constitutionally permissible to existing choice of law statutes. ${ }^{32}$

${ }^{2 x}$ See, e.g., Juenger, supra note 15, at 1521; Juenger, Trends in European Conflicts Law, 60 CoRnell L. REv. 969, 977-82 (1975).

29 Müller-Freienfels, Legal Equality of Husband and Wife and the Child's Welfare in Private International Law, in Essays in JuRISPRUdence IN HONOR OF Roscoe Pound 595, 605. 06 (1962).

so See GG art. CXVII, para. 1, which invalidates all legal provisions contrary to legal equality of sexes as of April 1,1953. Following this route, the Bundesverfassungsgericht determined that all statutes discriminating against illegitimate children, see GG art. VI, para. 5 , were to become void on October 20,1969 , the last day of the then current legislative term of the Federal Parliament (Bundestag). Judgment of January 29, 1969, BVerfG, W. Ger., 25 Bundesverfassungsgerichtsentscheidungen [BVerfGE] 167, 188.

"I As to the situation of West German courts after June 1, 1953, see Zweigert \& Puttfarken, Statutory Interpretation - Civilian Style, 44 Tur. L. REv. 704 (1970).

32 Cf. Judgment of December 18, 1953, BVerfG, W.Ger., 3 BVerfGE 225, 244 (in the wake of GG art. CXVII, para. 1, see note 30 supra, courts attempted to leave untouched as 


\section{B. An Illustration: Constitutional Equality and Conflicts Principles in Family Disputes}

Application of the law of the husband's or the father's nationality in marriage and child law cases has been increasingly subjected to criticism as violative of the equal rights guaranteed by many national constitutions. ${ }^{33}$ And indeed this view is gaining sway-the law of the husband and father is losing ground to the law of the common nationality or the common residence of husband and wife in matrimonial cases and to the law of the child in parental cases. ${ }^{34}$ For example, the appeals court of Berlin in a divorce suit brought by an Austrian against her German husband stated that the rule requiring application of the national law of the husband is unconstitutional because "it constitutes a discrimination against the wife in that it fails to accord equal value to the nationality of the wife." 35 The court applied the law of the complainant, the Austrian law. Yet how best to incorporate equality principles in domestic conflicts rules remains uncertain, and examination of this question nicely illustrates the more general problem of reconciling conflicts principles with constitutional mandates.

Courts and lawyers have generally not been eager to fashion new conflicts rules that accord with equality, for they naturally have sought to preserve their investment in existing laws. ${ }^{36}$ In some countries, application of equality principles may be limited by appeal to

much domestic relations law as possible); Judgment of July 14, 1953, BGHZ, W.Ger., 10 Entscheidungen des Bundesgerichtshofes in Zivilsachen [BbHZ] 226, 276 (same).

- E.g., Taneike, Private International Law and Equality of Sexes, 37 J. Crv. \& Comm. L. No. 2. Cf. P. Graulich, Principes de droit international privé: conflit de lois, conflit DE JURIDICTIONS 118-19 (1961) (Belgian statute enacting spousal equality throws primacy of the husband's law into doubt); Schwind, Entwurf eines Bundesgesetzes über das internationale Privat- und Prozebrecht, 12 ZEITSCHRIFT FOR REChTSVERGLeICHUNG 161, 215-18 (1971) (under Austrian law the idea of a legally equal partnership in marriage is inconsistent with primacy of the husband's law). But Sir Otto Kahn-Freund "feels great sympathy with those who answer the question in the affirmative," meaning that he sees no violation of the principle of equality in these conflicts rules. Kahn-Freund, supra note 24, at 234.

3 This development precedes the appearance of written constitutional provisions mandating equality of the sexes. For example, in France the increased use of the law of the common domicile in disputes between two spouses having different nationalities and the law of the child at the expense of the law of the father in parental cases, promoted by the famous Arrêt Rivière, Judgment of April 17, 1953, Cass. civ. 1re, Fr., [1953] Recueil Sirey 181, has been based on avoidance of the difficulty of having to choose one nationality when two are involved. As to paternity cases, see H. BatifFol \& P. LAGARDE, II DroIT INTERNATIONAL PRIvÉ 96, 98 (6th ed. 1976); Pallard, La filiation illégitime en droit international privé français, 41 Rev. Crit. D. Droit INT. P. 623, 637 (1952).

${ }_{35}$ Judgment of April 16, 1975, Kammergericht, Berlin, 22 FAMRZ 627, 627 (1975).

36 See P. LAGarde, Recherches SUR L'ORDRE PUBLIC EN DROIT INTERNATIONAL PRIVÉ 135 (1959): "On connait en effet l'hostilité des juges aux brusques revirements de jurisprudence, et leurs préférenches pour de lentes et insensibles évolutions." 
the constitutional principle guaranteeing the "unity of the family." This limitation is justified in countries such as Italy where, according to the constitution, the moral and legal equality of the spouses is "subject to the limitation provided by statute for the preservation of family unity." ${ }^{37}$ This qualification upon equality cuts deeply indeed.

Many in the Federal Republic of Germany are wary of the uncertainty that might result from rejection of the rule mandating application of the law of the husband's or father's nationality. ${ }^{38}$ They note the multitude of rules that have been suggested to replace the old principle: the national law of the plaintiff; the national law of the defendant; the law of the last common nationality; the law of the last common residence; and rules that refer to the "stronger" or "weaker" 39 law in order to permit, as a practical matter, application of whatever law leads to the desired result. But this difficulty should be short-lived. Once the legislature enacts a constitutional rule to govern this situation or the highest court speaks to the question, the uncertainty will be largely dissipated.

Several commentators have suggested that conflict with equal rights principles may be avoided by giving the parties freedom to choose the applicable law among the common national law of the parties, the national law of one of the parties, and the law of the place of residence. ${ }^{40}$ This proposal neglects an important consideration. In torts or contracts, allowing the parties to choose the governing law seems sensible because they are free to create, vary, or abrogate their substantive legal rights and obligations. In marriage law, by contrast, public policy considerations restrict the parties' freedom to alter their obligations inter se, although there is a trend toward consensual divorce in most countries. In child law, granting the parties freedom to vary their legal relationships would be inconsistent with the court's duty to protect the child, whose welfare is the controlling concern.

Some German courts, ${ }^{41}$ in particular the appeals court of Ba-

${ }^{37}$ Cost. art. XXIX, para. 2. See T. Ballarino, supra note 11, at 77-80.

* See Henrich, supra note 15, at 492 n.7, for further references.

3r See, e.g., T. Soergel \& W. Siebert, 9 Büragrrliches Gesetzbuch mit EinführUNGSGESETZ UND NEBENGESETZEN 141-44 (G. Kegel \& H. Länge eds. supp. 1975); J. STAUDINGER; EinfüHrungsGeseTz zUM BürgerLichen Gesetzbuch pt. 3 at 49 (F. Gamillscheg ed. 10/11 ed. 1973).

to E.g., Sturm, Zur Gleichberechtigung im deutschen internationalen Privatrecht, in RECHTSVERGLEICHUNG UND RECHTSVEREINHEITLICHUNG: FESTSCHRIFT ZUM FÜNFZIGJÄHRIGEN BESTEHEN DES INSTITUTS FÜR AUSLÄNDISCHES UND INTERNATIONALES PRIVAT- UND WIRTSCHAFTSRECHT DER UNIVERSTTÄT HEJDELBERG 155, 166 (1967).

"Jügment of July 25, 1973, LG Munster i.W., W. Ger., 21 FAMRZ 132 (1974) note H. 
varia, have avoided abrogating the rule requiring application of the national law of the husband by reasoning that, on the facts of the particular case, application of the national law of the wife would have yielded the same concrete result. ${ }^{42}$ This approach is questionable, however, because the national law of the wife referred to may be the law she acquired through marriage, not the law of her own nationality.

On the other hand, the appeals court of Stuttgart ruled, in a child custody proceeding subsequent to a divorce, that application of the law of the father would violate the equal rights principle as between the parents. The court held that it is the "task of the case law to fill the void created by the invalidation of unconstitutional rules. . . . [A]pplication of the law of the place of usual residence of the child (in Austria) is here the most just solution." 43 This decision is especially remarkable because the court would have reached the same result-application of Austrian law-had it applied the German choice of law statute, Article 19 of the Introductory Law of the German Civil Code. Apparently the court was determined to declare Article 19 unconstitutional. ${ }^{44}$

There is a certain danger in relying on constitutional considerations to invalidate choice of law principles. The tendency might develop to view a single constitutional choice of law solution as the only constitutional one, and a state of affairs in which future changes are impossible is clearly undesirable. This view has already surfaced. For example, Stöcker, a member of the federal ministry of justice in Germany, has stated that "in child law every reference to a law other than the law of the child's residence is unconstitutional, given the guardianship duty of the parents and of the governmental authorities." 45 This position is overly inflexible. It is often

\footnotetext{
Strumpell (divorce valid under laws of both countries); Judgment of May 17, 1974, OLG Dusseldorf, W. Ger., 21 FamRZ 528 (1974) note G. Beitzke (parties shared dual citizenship).

12 Judgment of April 10, 1975, Bayrisches Oberstes Landesgericht, W. Ger., 28 NJW 1602,1603 (1975) (wife had dual citizenship in country of husband).

is Judgment of June 23, 1975, OLG Stuttgart, W. Ger., 22 FAMRZ 644, 646 (1975).

"Proposals to choose the law of the marital residence in marriage cases and the native law of the child in child cases have won many supporters worldwide. See, e.g., MullerFreienfels, supra note 29, at 607-10, 622-48. Modern Japanese scholars have favored this solution on constitutional grounds, Sawaki, JAP. AnNunL OF LAw \& A. PoL. 76 (1960); Taneike, supra note 33, a view of great practical importance in light of the availability of constitutional review of statutes by the Japanese lower courts. E. Hillach, supre note 15 , at 59 .

is Stöcker, Reform des deutschen internationalen Kindschaftsrechts durch Anwendung des Grundgesetzes, 28 Das Standesamt 209, 210-11 (1975). See also H. KRuger, Die

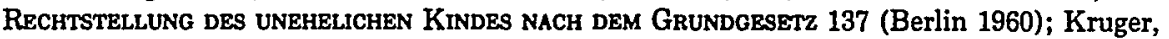
Unecheliche Kinder, in IV pt. 1 DIE GRUNDREChTE: HaNDBUCH DER TheORIE UNd Praxis DER GRUNDRECHTE 325, 338 (K. Betterman, H. Nipperdey \& U. Scheuner eds. 1960).
} 
difficult to amend constitutions. In several countries constitutions may not be amended by statute and in others statutory constitutional amendments require supermajorities. ${ }^{46}$ More fundamentally, it is doubtful that constitutional provisions require a single choice of law solution instead of simply proscribing certain solutions.

The problem of inflexibility is somewhat reduced by the ability of the highest constitutional court to change its view of the effect of constitutional principles on a particular conflicts rule, especially after a change of judges. In most countries, such courts are not bound by their prior decisions. Nevertheless, these reversals must be kept within narrow and principled bounds, lest respect for the court's decisions be undermined.

\section{Foreign Laws That Contravene the Domestic Constitution}

Does domestic constitutional law require domestic courts to decline to apply foreign laws that would be unconstitutional if enacted by the domestic legislature? This is a matter of the scope of the particular domestic constitutional provision. In countries that accord the constitution supremacy over other types of law, the scope of constitutional provisions cannot be resolved by the rules of private international law, for then constitutional law would be subordinate to conflicts law. ${ }^{47}$ Rather, constitutional law itself must be the source for determining the range of application of constitutional rights. ${ }^{48}$

This function of constitutional adjudication should be distinguished from incorporation of basic constitutional principles in the public order clause. The public order clause contained in conflicts statutes, and its case law analogue in countries where conflicts principles are developed in the courts, prohibit application of an otherwise applicable foreign law when that law is contrary to the forum's public policy. In contrast, a body of constitutionally-based rules delineating the scope of constitutional provisions would come into play one step earlier. If, for example, the forum constitution expressly reaches situations involving foreign elements, there is no

\footnotetext{
"For example, GG art. LXXIX, para. 2, provides that those portions of the German Constitution which can be amended require a two-thirds majority of both federal parliamentary houses. GG art. LXXIX, para. 3, further provides that certain portions of the Constitution, notably those protecting the inviolability of human dignity, cannot be changed.

17 See Judgment of April 29, 1964, BGH, W. Ger., 20 JZ 99, 101 (1965) note W. Wengler; Bernstein, supra note 1, at 2273. But see Ferid, supra note 42, at 143; Gamillscheg, Die Grundrechte bei der Anwendung ausländischen Rechts, in FEstschrift Für HANS CARL NıpPERDEY zUM 70. Geburtstag 21. JANUAR 1965 323, 327 (1965); Judgment of April 29, 1964, BGH, W. Ger., 20 JZ 99, 100 (1965) note W. Wengler (opinion of the court).

${ }^{4}$ Bernstein, supra note 1 , at 2275 , strongly favors this solution.
} 
need to interpret and apply the public order clause so as to avoid applying a foreign law that contravenes the constitution of the forum state. In short, the question is neither one of ordinary private international law nor one of interpretation of the reach of what has been called the "cornerstone" of substantive law justice, the public order clause..$^{49}$ It is a question of constitutional interpretation.

Answering this question will not be an easy task. Most constitutional articles do not clearly specify their sphere of application. Thus article 3 of the Italian constitution, which declares that the guarantee of equal rights applies only to Italians, is exceptional.50 Moreover, the historical materials indicative of the framers' purposes usually shed little light on this question; in most cases the matter of application to international controversies simply was not considered. Furthermore, conceptual distinctions between "general" human rights, national basic rights, and citizenship rights, ${ }^{51}$ distinctions designed to help ascertain the kinds of people protected by particular constitutional safeguards, do not appear fruitful in this context. ${ }^{52}$ Distinctions between "human" and "basic" rights, turning on how fundamental the constitutional rights are, have also proved unproductive. Analysis wedded to abstract concepts should be eschewed in favor of careful consideration of the interests involved in each case.

An old, impressive illustration of the conceptual approach to this question was provided by the Swiss Federal Court in the last century. Decades before the highly-touted discovery of constitutional conflicts law, the court in 1897 held that to determine whether the permissibility of a contemplated marriage should be governed by foreign or Swiss law was to answer the wrong question. Rather, the court ruled that the right to marry guaranteed in the Swiss Constitution ${ }^{53}$ applied to the particular prospective spouses. The court reasoned that "the right to marry is viewed as a right which is based on human nature, an emanation of a free person" and a right to which all persons subject to Swiss sovereignty (in particular, Swiss residents) are entitled, regardless of citizenship. ${ }^{54}$

1" G. KEGEL, supra note 25 , at 63 .

so Cost. art. III.

st See, e.g., H. von Mangold \& F. Klenn, I Das Bonner Grundgesetz 97-100 (2d ed. 1957) for an explanation of such distinctions.

32 Contra, Ferid, supra note 24, at 135 . Ferid does not examine conflict rules for consistency with "basic rights." "Basic rights" (Bürgerrechte) extend only to German citizens. He would apply concerns inherent in general human rights (allgemeine Menschenrechte) to conflict rules, since ignoring these rights would damage the principle of equality.

s3 Bundesverfasung art. LIV (Switz.).

st Judgment of December 16, 1897, BG, Switz., 23 Pt.2 Entscheidungen des schweizer- 
Courts should not mistake the primacy of their constitutions and the absence of explicit restrictions on the purview of constitutional provisions as mandates for unlimited application of their constitutions to multinational controversies. There are strong reasons for proceeding cautiously. Employment of the forum state's constitution, like the more traditional use of the public order clause, generally results in application of the lex fori. ${ }^{55}$ The leading case in the German Federal Constitutional Court, the so-called Spaniard decision, ${ }^{56}$ indicates that the consequence of applying domestic constitutional law to conflicts problems will generally be application of the substantive law of the forum. This trend toward application of the law of the forum, coupled with the widespread and increasing acceptance of long-arm statutes for assuming jurisdiction, promotes forum shopping by the plaintiff. ${ }^{57}$ Private international law and its aim of an international justice will be abandoned if this development proceeds unchecked.

The impact of the ascendancy of constitutional law in the conflicts area on individual liberty is somewhat difficult to predict. In the United States, the importation of constitutional considerations into family law by the Supreme Court, for example, has enhanced individual liberty. ${ }^{58}$ In France, by contrast, civil liberties are more effectively protected through the Code Civil than through the vague

ischen Bundesgerichtes, amtliche Sammlung [BGE] I 1390, 1392. Today, however, Swiss courts reach this result by application of a statute (Art. 7c NAG). See Judgment of June 3, 1971, BG, Switz., 97 BGE I 389, 410 (applying statute without mention of the constitution); Judgment of Nov. 11, 1954, BG, Switz., 80 BGE I 427, 430-31 (constitution comes into play only insofar as statutes must be interpreted in light of the constitution); Judgment of March 2, 1942, BG, Switz., 68 BGEI 73, 79 (statutory law, as qualified by the constitution, applies).

ss Kegel, supra note 26, at 234, states: "Public policy is a parade ground for the basic rule of the lex fori." See also F. Juenger, Zum Wandel des internationalen Privatrechts 21 (1974).

s6 Judgement of May 5, 1971, BVerfG, W. Ger., 31 BVerfGE 58, 36 RabelsZ 145 (1972), discussed in Juenger, supra note 28, at 977-82; Juenger, 20 J. COMP. L. 290 (1972); F. JuENGER, supra note 55, at 17-22.

${ }^{57}$ Cf. A. Ehrenzweig, Conflicts in a Nutshell 50-52 (3d ed. 1974) (discusses problem of forum shopping in American law if lex fori is applied); R. WeInTRAuB, CoMmENTARY ON THE CoNFLICT OF LAws 67-69 (1971) (discusses relationship between conflicts rules and jurisdiction in American law, with special attention to long arm statutes and their "attenuated" idea of jurisdiction). In Shaffer v. Heitner, 433 U.S. 186, 207-212 (1977), the Court restricted exercise of quasi-in-rem jurisdiction substantially. The Court held that the standard of determining whether an exercise of quasi-in-rem jurisdiction is consistent with the due process clause is the minimum contacts standard elucidated in International Shoe Co. v. Washington, 326 U.S. 310 (1945).

ss See, e.g., Zablocki v. Redhail, 98 S. Ct. 673 (1978); H. Krause, Family LaW in a NuTSHELL 16 (1977), stating that the state-federal conflict in family law "has centered on the issue of state regulation us. individual rights, with the United States Constitution generally taking the side of the individual." 
pronouncements of the constitutional Declaration of Human Rights. Indeed, the French praise their Code as "une vraie constitution." 58

\section{Conclusion}

The experiences of different countries do not suggest that constitutional considerations should be neglected in choice of law decisions. On the contrary, they prove it salutary that constitutional law considerations are used to influence conflicts law decisions. In European private international law, the process of achieving appropriate solutions to concrete cases has for too long ignored constitutional law. By contrast, constitutional law has long been viewed in the United States as setting the boundaries for permissible choice of law decisions. Considerable room for radically different but equally constitutional conflicts decisions characterizes the American system.

Thus, constitutional arguments do not exclude the principled weighing of policy interests that is conflicts law. But there is a danger that legitimate private international law considerations may become seriously submerged. And the need for the certainty afforded by identifiable, workable conflicts rules is not diminished by a constitutional orientation. Coexistence in a flexible rule-governed process of decision is needed, a process that considers both private "international" law and "national" constitutional law from the standpoint of doing justice between the litigating individuals and in the light of considerations of social policy. It is an old experience of the comparative lawyer that the problems that arise in comparing different private law concepts of various countries, such as property, contract, or succession, are usually more complicated than the questions arising from comparing constitutional postulates such as equality of the sexes or equality of legitimate and illegitimate children.

Many basic constitutional ideas, promoted by the human rights discussions, are gaining adherents in the international community. Consequently, the international acceptability and the fairness to the parties of applying constitutional principles to international conflicts questions are increased. Private international law is too narrow unless constitutional ideas are considered.

" Cf. G. Boemmer, Einführung in DAS Bürgerliche Recht 73 (1954) (German law is phrased at such a level of abstraction that it is too distant from the image of life, while in France specific, simple law has content even in the absence of judicial interpretation). 